\title{
PENERAPAN COOPERATIVE LEARNING DALAM PENGAJARAN SPEAKING PADA MATERI ASKING FOR AND GIVING OPINION
}

\author{
Nur Endah Sulistyorini \\ SMKN 5 Yogyakarta \\ email: nesmkn5@gmail.com
}

\begin{abstract}
ABSTRAK
Belajar bahasa Inggris sebagai bahasa asing merupakan proses pembelajaran jangka panjang. Proses tersebut meliputi menginternalisasikan budaya pada proses pengajaran. Dengan kata lain, belajar bahasa membutuhkan waktu dan pembiasaan yang berkesinanbungan. Dalam proses tersebut motivasi belajar siswa dalam pembelajaran bahasa memiliki hubungan yang erat dengan kemampuan mereka tentang bahasa target. Mengajarkan bahasa yaitu menciptakan suasana berkomunikasi yang senantiasa merangsang keingintahuan mereka tentang bahasa target. Dalam proses belajar mengajar bahasa Inggris, guru menghadapi beberapa kondisi dimana peserta didik memiliki karakteristik dan minat masing-masing. Mereka cenderung memiliki tingkat motivasi belajar yang berbeda dalam proses pembelajaran bahasa Inggris. Kondisi ini terkait dengan latar belakang mereka dimana hal tersebut mempengaruhi motivasi belajar bahasa Inggris. Dengan kondisi tersebut, perlu adanya kerja sama antar siswa untuk saling menguatkan dan memotivasi dalam proses pembelajaran bahasa. Guru harus mencoba berbagai model pembelajaran yang paling cocok untuk memecahkan masalah di kelasnya sehingga proses belajar mengajar berjalan sesuai harapan. Tulisan ini membahas tentang penerapan model pembelajaran Cooperative Learning, bagaimana langkah-langkah pembelajarannya dan apakah model pembelajaran tersebut dapat menciptakan lingkungan belajar yang efektif, aktif dan menyenangkan.
\end{abstract}

Kata kunci: Cooperative Learning, Pembelajaran Speaking

\section{PENDAHULUAN}

Keberhasilan suatu proses belajar mengajar ditentukan oleh beberapa faktor. Salah satu faktor penentu keberhasilan suatu proses pembelajaran adalah seorang guru. Seorang guru harus mampu menciptakan proses pembelajaran yang efektif sehingga siswa dengan mudah mempelajari sesuatu. Menurut Popham dan Baker ( 1992) dalam (Suyanto \& Jihad, 2013), pada hakikatnya proses pembelajaran yang efektif terjadi jika guru dapat mengubah kemampuan dan persepsi siswa dari yang sulit mempelajari sesuatu menjadi mudah mempelajarinya. Proses belajar yang 
efektif sangat bergantung pada pemilihan dan penggunaan metode pembelajaran untuk memaksimalkan pembelajaran. Hal ini bisa diartikan bahwa seorang guru mengambil peran penting dalam mengelola kelasnya sehingga tujuan utama suatu proses pembelajaran bisa tercapai.

Mengajar Bahasa Inggris yang merupakan Bahasa Asing sangat membutuhkan kemampuan ekstra dari seorang guru. Guru dituntut untuk lebih memutar otak untuk kreatif dan inovatif dalam proses belajar mengajar karena sebagai Bahasa Asing, Bahasa Inggris masih merupakan hal yang membuat sebagian siswa mengalami kesulitan dan tidak punya motivasi belajar. Menurut (Suyanto \& Jihad, 2013), ada dua hal yang diperlukan seorang guru untuk menciptakan suatu proses belajar-mengajar yang efektif. Pertama, perlu dilakukannya kegiatan analisis kebutuhan belajar siswa. Kebutuhan siswa adalah bagaimana menganalisis hubungan antara kemampuan dan harapan siswa dari proses pembelajarannya. Kedua, adanya gambaran seperti apa sistem ujian yag dipakai sehingga pembelajaran yang efektif harus mempunyai syarat kesesuaian antara kebutuhan belajar siswa dan system ujian.

Dalam rangka mengefektifkan proses belajar-mengajar, seorang guru membutuhan strategi yang bisa membantu meningkatkan motivasi belajar siswa. SMKN 5 Yogyakarta, sebagai sekolah yang berbasis seni kerajinan, dan kedepannya mereka dituntut untuk bisa berkomunikasi dengan banyak orang baik dari dalam maupun luar negeri, sudah seharusnya siswa dibekali kemampuan unuk berinteraksi dalam Bahasa Inggris. Akan tetapi, dalam proses belajar mengajar Bahasa Inggris, mereka terlihat tidak begitu bersemangat dan cenderung merasa kesulitan karena malu untuk berbicara dan takut salah.

Permasalahan yang sering dihadapi dalam proses pembelajaran yaitu banyaknya siswa yang pasif sehingga guru kesulitan untuk merubah suasana kelas menjadi efektif, aktif dan menyenangkan khususnya dalam pembiasaan speaking; siswa cenderung merasa takut berbicara apalagi memakai Bahasa Inggris; guru mengalami kesulitan dalam menumbuhkan motivasi siswa yang merasa tidak tertarik dengan Bahasa Inggris karena merasa kesulitan dan asing dengan kosa kata Bahasa Inggris; selain guru masih kesulitan untuk menciptakan berbagai 
aktivitas yang berhubungan dengan praktek speaking dalam pembelajaran Bahasa Inggris sehingga membuat siswa semakin termotivasi dalam belajar .

Berdasarkan paparan di atas, penulis mencoba untuk menerapkan pembelajaran menggunakan model Cooperative Learning dalam pembelajaran Bahasa Inggris dalam materi Asking for and Giving Opinion untuk kelas XI dimana penerapan model tersebut mengakomodir tuntutan Kurikulum 2013 revisi 2018 yang tetap berfokus pada siswa dalam proses belajar mengajar dan mengembangkan karakter kerja sama dalam proses pembelajarannya. Dalam tulisan ini, penulis ingin menjelaskan tahapan pembelajaran Bahasa Inggris menggunakan model Cooperative Learning dan bagaimana metode tersebut dapat meningkatkan keaktifan dan motivasi siswa dalam proses pembelajaran Bahasa Inggris

\section{METODE}

Tulisan ini hasil dari pendalaman studi pustaka yang di dalamnya mengaitkan teori satu dan teori yang lain yang tersaji dalam deskripsi permasalahan dan disertai pemaparan analisis terkait model Cooperative Learning yang diterapkan dalam proses pembelajaran Bahasa Inggris.

\section{HASIL DAN PEMBAHASAN}

Belajar bisa diartikan sebagai proses dari tidak tahu menjadi tahu yang melibatkan keaktifan pembelajar itu sendiri. (Richards \& Rodgers, 1986) menyatakan bahwa "learning is acquiring or getting of knowledge of a subject or a skill by study, experience, or instruction".

Hal ini bisa diartikan bahwa belajar adalah proses pemerolehan pengetahuan atau ketrampilan melalui pengalaman atau melakukan sesuatu. Lebih jauh lagi bahwa belajar tidak bisa dipisahkan dari hal yang disebut mengajar.

"teaching is showing or helping someone to learn how to do something, giving instructions, guiding in the study of something, providing with knowledge, causing to know or understand. More, teaching is guiding and facilitating learning, enabling the learner to learn, setting condition to learn. So, how the learner learns will determine teacher's philosophy of education, 
teaching style, approach, method, and classroom technique (Richards \& Rodgers, 1986).

Dengan kata lain, mengajar adalah menunjukkan, mengarahkan atau membantu orang lain untuk tahu bagaimana melakukan sesuatu, memberi instruksi, memimpin dan memfasilitasi seseorang untuk belajar. Lebih jauh lagi, (Harmer, 1998) menyatakan bahwa "language learners need to be motivated, be exposed to language, and give chances to use it. Therefore, there are elements need to be present in a language classroom to help students learn effectively. They are firstly, engage. This is the point in a teaching sequence where teachers try to arouse the students' interest, thus involving their emotion. Secondly, study. Study activities are those where the students are asked to focus in on language (or information ) and how it is constructed. The last, activate. This element describes execises and activities which are designed to get students using language as freely and communicatively as they can."

Untuk mewujudkan proses belajar mengajar yang efektif, ada tiga hal yang harus ada di dalamnya. Pertama, siswa harus dilibatkan dalam setiap proses pembelajaran, kedua siswa harus diajak belajar atau mengalami sendiri proses menemukan sesuatu/ membuat sesuatu dan yang terakhir siswa diajak untuk aktif berkomunikasi seluas-luasnya tanpa dihalangi adanya aturan-aturan. Biarlah siswa belajar menggunakan bahasa secara bebas ,karena dari proses itulah mereka bisa belajar menjadi lebih baik. Selain itu kerja sama dan saling memotivasi antar teman akan membuat proses belajar berjalan dengan lebih baik.

Suyanto dan (Suyanto \& Jihad, 2013) menyatakan bahwa pembelajaran kooperatif merupakan model pembelajaran yang mengutamakan kerja sama antarsiswa untuk mencapai tujuan pembelajaran. Ciri-ciri model pembelajaran kooperatif adalah:

a. Tujuannya menuntaskan materi dengan cara siswa belajara dalam kelompok secara kooperatif;

b. Dalam satu kelompok ada tiga jenis kemampuan siswa, yaitu tinggi, sedang dan rendah;

c. Bila dalam kelas ada berbagai ras/ suku diupayakan dalam satu kelompok mengakomodir keberagaman tersebut; 
d. Penghargaan atas keberhasilan belajar lebih diutamakan pada kerja kelompok daripada perorangan

Menurut (Slavin, 2015) dalam (Suyanto \& Jihad, 2013) Cooperative Learning memiliki pendekatan atau serangkaian model yang khusus dirancang untuk memberi dorongan kepada siswa agar bekerja sama selama proses pembelajaran dalam struktur kelompok yang heterogen. Lebih jauh lagi, biasanya dalam penerapan kooperatif learning guru memperoleh hal positif dengan diberlakukannya kelompok heterogen, pertama, kelompok yang heterogen memberikan kesematan yang luas bagi siswa untuk salng mengajar dan mendukung. Kedua, kelompok ini meningkatkan relasi dan interaksi antar ras, etnik, dan gender, sehingga sangat positif untuk membiasakan siswa dalam kehidupan yang plural. Ketiga, kelompok heterogen memudahkan pengelolaan kelas karena dengan adanya satu orang yang berkemampuan akademis tinggi, guru otomatis mempunyai satu asisten untuk tiap kelompok.

Model pembelajaran kooperatif memiliki basis pada teori psikologi kognitif dan teori pembelajaran sosial. Fokus pembelajaran kooperatif tidak saja tertumpu pada apa yang dilakukan peserta didik tetapi juga pada apa yang dipikirkan peserta didik selama aktivitas belajar berlangsung. Informasi yang ada pada kurikulum tidak ditransfer begitu saja oleh guru kepada peserta didik, tetapi peserta didik difasilitasi dan dimotivasi untuk berinteraksi dengan peserta didik lain dalam kelompok, dengan guru dan dengan bahan ajar secara optimal agar siswa mampu mengkonstruksi pengetahuannya sendiri. Dalam model pembelajaran kooperatif, guru berperan sebagai fasilitator, penyedia sumber belajar bagi peserta didik, pembimbing peserta didik dalam belajar kelompok, pemberi motivasi peserta didik dalam memecahkan masalah, dan sebagai pelatih peserta didik agar memiliki ketrampilan kooperatif.

Mengacu pada (Suyanto \& Jihad, 2013) tentang beberapa langkah pembelajaran Cooperative Learning, dalam tulisan ini disampaikan detil langkah pembelajaran Cooperative Learning. Berikut adalah detail langkah -langkahnya:

1. Guru menjelaskan tentang tujuan pembelajaran sealigus memberikan motivasi belajar dan menggiring siswa untuk memahami apa yang akan dipelajari. 
2. Guru menjelaskan secara general materi yang akan disampaikan dengan bantuan video dan beberapa teks bacaan yang berhubungan dengan asking for and giving opinion

3. Guru memberikan petunjuk/ arahan tentang beberapa kata yang dipakai dalam asking for and giving opinion

4. Guru memberikan model dengan memutarkan beberapa video tentang asking for and giving opinion yang akan dipelajari

5. Siswa membentuk kelompok yang dipandu oleh guru dimana tiap kelompok dipastikan terdiri dari beberapa siswa yang mempunyai kemampuan yang heterogen dan setelah itu guru memberikan tema/ masalah ( dalam bentuk foto ttg kondisi sosial) atau tugas yang harus diselesaikan dalam kelompok.

6. Siswa membicarakan tema atau topik masalah yang diberikan dan mendiskusikan solusi bersama dalam kelompok.

7. Siswa saling memberikan pendapatnya mengenai topik yang diberikan dan salah satu menuliskan kesimpulan dari pendapat kelompok.

8. Guru bertindak sebagai pengamat dan fasilitator dimana akan memberikan bantuan apabila ada kelompok yang membutuhkan bimbingan atau measa kesulitan dalam mengerjakan tugas.

9. Guru memberikan kebebasan siswa untuk berekspresi atau berpendapat dalam kelompok dimana dalam satu kelompok ada siswa yang menjadi ketua yang bisa memimpin dan mengarahkan kelompoknya dalam mengerjakan tugasnya.

10. Siswa dalam kelompok mempresentasikan hasil diskusi kelompok di depan kelas

11. Guru dan kelompok lain memberikan masukan dan feed back yang membangun

12. Guru memberikan apresiasi dan penghargaan yang setinggi-tingginya atas kerjasama dalam group dan memotivasi siswa dengan cara melakukan refleksi. 
Setiap proses mencobakan cara baru dalam pembelajaran dipastikan ada hambatan-hambatan yang muncul pada saat pelaksanaan proses mengajar materi asking for and giving dengan menerapkan Cooperative Learning adalah sebagai berikut:

1. Dalam pembentukan kelompok masih memakan waktu lama untuk memastikan penyebaran kemampuan tiap siswa di tiap kelompok.

2. Sebagian besar siswa masih malu- malu dalam mengungkapkan pendapatnya

3. Siswa kesulitan dalam pronunciation.

4. Siswa masih sering menggunakan Bahasa Indonesia.

5. Sebagian siswa harus selalu diingatkan akan tanggung jawabnya dalam kelompok sehingga tugas bisa diselesaikan .

6. Sebagian siswa kurang rasa kepercayaan diri yang kurang terhadap kemampuan yang dimilikinya ketika harus melakukan speaking practice.

7. Sebagian siswa kurang termotivasi untuk melakukan tugasnya.

Kondisi siswa di kelas pada dasarnya sangat kooperatif dalam proses belajar mengajar Bahasa Inggris. Akan tetapi sebagian besar dari siswa merasa tidak percaya diri apabila mereka dihadapkan pada materi pembelajaran yang mengharuskan mereka menyampaikan ide atau pendapatnya dalam Bahasa Inggris. Berdasarkan beberapa pemantauan dan pengambilan nilai praktek speaking, sebagian besar siswa mendapatkan hasil yang kurang maksimal. Sebagian besar siswa kurang percaya diri dan ragu-ragu dalam mengungkapkan idenya karena mereka terkendala kosa kata dan bagaimana mengungkapkan idenya dalam Bahasa Inggris.

Hasil yang dicapai setelah menerapkan Cooperative Learning untuk pembelajaran materi asking for and giving opinion secara umum sangat baik. Hasil penilaian yang berasal dari penilaian hasil akhir rata-rata kelas baik. Sementara untuk kondisi belajar dalam kelas sangat berubah menjadi lebih terlibat aktif dan termotivasi. Siswa dalam kelompok terlihat sangat antusias dalam berdiskusi dan saling memberikan pendapatnya meskipun penggunaan Bahasa Inggrisnya belum sepenuhnya benar dan tepat. Mereka terlihat tidak tertekan 
bersemangat dikarenakan bekerja dalam kelompok. Kemandirian mereka terlihat ketika mereka harus mempresentasikan hasil kerja kelompoknya dimana mereka saling membagi peran pada waktu maju ke depan kelas. Siswa menjadi lebih aktif bertanya dan kelas menjadi lebih hidup dan menyenangkan. Dari hasil tanya jawab secara tidak langsung, sebagian besar siswa merasa lebih senang dan termotivasi dengan menggunakan Cooperative Learning dalam pembelajaran Bahasa Inggris dengan topik asking for and giving opinion. Hal tersebut dapat diartikan bahwa siswa sudah dapat merasakan keunggulan dari model pembelajaran ini dan merasakan hasilnya.

Penilaian ditentukan oleh siswa dari kelompok lain dan dari guru, dengan melihat pada aspek :

a. Kerjasama dalam kelompok dilihat dari seberapa aktif mereka saling membantu ketika mengerjakan tugas

b. Pengetahuan dilihat dari seberapa komplek kalimat yang ditulis dan dipresentasikan mengenai topik yang diberikan sebagai tugas kelompok

c. Kemampuan mengkomunikasikan topik asking for and giving opinion merupakan aspek yang dinilai juga dengan mendasarkan pada bagaimana mereka dengan percaya diri dan bekerja sama dalam kelompok dalam menyelesaikan tugas. Yang terpenting adalah kemauan mereka dalam berbicara atau mengungkapkan pendapat dan tersampaikannya pendapat mereka kepada kelompok lain dan bagaimana menjawab pertanyaan dari kelompok lain dalam rangka mempertahankan opini atau pendapat kelompok.

Penggunaan Cooperative Learning dalam pembelajaran Bahasa Inggris untuk mempelajari materi asking for and giving opinion dapat dikembangkan dengan topik yang lain atau skill yang lain seperti untuk materi writing, listening ataupun reading. Pendampingan dalam pembentukan kelompok akan memudahkan siswa dalam mengikuti proses pembelajaran, maka dari itu guru tetap harus ikut campur dalam proses pembentukan kelompok untuk mendapatkan hasil pembelajaran yang sesuai harapan. Pemantauan keterlaksanaan kerja sama dalam kelompok harus lebih ditekankan untuk menghindari rasa dominan dari salah seorang anggota kelompok dan sebaliknya memastikan tidak ada anggota 
kelompok yang pasif. Pilihan tugas yang tepat akan membuat kondisi proses belajar mengajar semakin hidup dan siswa belajar sambil melakukan/ menyelesaikan tugas. Oleh karena itu guru harus lebih selektif dalam memilih jenis kegiatan yang mengarahkan pada siswa bisa berexperimen sendiri dan berkembang rasa kemandiriannya dalam proses belajarnya. Pada dasarnya, pembelajaran dengan menerapkan model cooperative learning mempersiapkan siswa untuk lebih mandiri, meningkat rasa kepemimpinannya, kerja samanya dan sangat membuat nyaman untuk siswa yang merasa belum kompeten karena dalam kelompok siswa bisa saling bantu satu sama lain.

\section{SIMPULAN}

Cooperative learning adalah salah satu strategi belajar mengajar yang menekankan pada sikap atau perilaku bersama dalam bekerja atau membantu di antara sesama dalam struktur kerjasama yang teratur dalam kelompok, yang terdiri dari dua orang atau lebih. Model pembelajaran kooperatif dikembangkan untuk mencapai setidak-tidaknya tiga tujuan pembelajaran yaitu Hasil belajar akademik, penerimaan terhadap perbedaan individu, dan pengembangan keterampilan sosial.

Penerapan model pembelajaran Cooperative Learning dalam pembelajaran Bahasa Inggris untuk mempelajari materi asking for and giving opinion ini sangat cocok dengan kebutuhan siswa yang akan terjun di dunia kerja dimana dihadapkan pada kemampuan memimpin, bekerja sama dalam tim dan juga sikap kemandirian yang tentu saja sangat dibutuhkan dalam dunia kerja. Pada proses pembelajaran, siswa begitu terlibat dan mempunyai motivasi yang besar untuk berpartisipasi aktif dalam pengerjaan tugas dalam kelompok. Mereka terlihat dalam kondisi nyaman dalam belajar bersama kelompoknya karena mereka akan saling bantu untuk memecahkan masalah dalam proses belajar mengajar. Kesulitan belajar dan kurangnya motivasi dalam pembelajaran Bahasa Inggris menjadi tidak muncul setelah mereka diberikan suatu kegiatan/ tugas yang sesuai dengan kebutuhan mereka di dunia kerja dan diselesaikan dalam kelompok.

\section{DAFTAR PUSTAKA}

Harmer, J. (1998). How to Teach English. Longman Publishing Group. 
Richards, J. C., \& Rodgers, T. S. (1986). Approaches and Methods in Language Teaching. In Cambridge University Press. https://doi.org/10.3138/cmlr.44.3.551

Slavin, R. E. (2015). Cooperative learning : teori, riset dan praktik (Zubaedi (ed.); 15th ed.). Nusamedia.

Suyanto, \& Jihad, A. (2013). Menjadi guru profesional : Strategi meningkatkan kualifikasi dan kualitas guru di era global. Erlangga. 